\title{
Predatory bacteria in combination with solar disinfection and solar photocatalysis for the treatment of rainwater
}

Waso, M., Khan, S., Singh, A., McMichael, S., Ahmed, W., Fernandez-lbanez, P., Byrne, J., \& Khan, W. (2020).

Predatory bacteria in combination with solar disinfection and solar photocatalysis for the treatment of rainwater. Water Research, 169(1), 1. [115281]. https://doi.org/10.1016/j.watres.2019.115281

Link to publication record in Ulster University Research Portal

\section{Published in:}

Water Research

Publication Status:

Published (in print/issue): 01/02/2020

DOI:

10.1016/j.watres.2019.115281

\section{Document Version}

Author Accepted version

\section{General rights}

Copyright for the publications made accessible via Ulster University's Research Portal is retained by the author(s) and / or other copyright owners and it is a condition of accessing these publications that users recognise and abide by the legal requirements associated with these rights.

\section{Take down policy}

The Research Portal is Ulster University's institutional repository that provides access to Ulster's research outputs. Every effort has been made to ensure that content in the Research Portal does not infringe any person's rights, or applicable UK laws. If you discover content in the Research Portal that you believe breaches copyright or violates any law, please contact pure-support@ulster.ac.uk. 
1 Predatory bacteria in combination with solar disinfection and solar photocatalysis for the

2 treatment of rainwater

3

4 Waso, M. ${ }^{1}$, Khan, S. ${ }^{2}$, Singh, A. ${ }^{3}$, McMichael, S. ${ }^{3}$, Ahmed, W. ${ }^{4}$, Fernández-lbáñez, P. ${ }^{3}$, Byrne, J.A. ${ }^{3}$ 5 and Khan, W. ${ }^{1 *}$

6

71 Department of Microbiology, Faculty of Science, Stellenbosch University, Private Bag X1, 8 Stellenbosch, 7602, South Africa.

92 Faculty of Health Sciences, University of Johannesburg, PO Box 17011, Doornfontein, 2028, South 10 Africa.

$11{ }^{3}$ Nanotechnology and Integrated BioEngineering Centre, Ulster University, Jordanstown Campus, 12 Shore Road, Newtownabbey, Belfast, BT37 0QB, Northern Ireland.

${ }^{4}$ CSIRO Land and Water, Ecosciences Precinct, 41 Boggo Road, Queensland, 4102, Australia.

22 *Address Correspondence to W. Khan; Email: wesaal@sun.ac.za; Tel: +27 21808 5804; Fax: +27 $23 \quad 218085846$ 


\section{Abstract}

The predatory bacterium, Bdellovibrio bacteriovorus, was applied as a biological pre-treatment to solar disinfection and solar photocatalytic disinfection for rainwater treatment. The photocatalyst used was immobilised titanium-dioxide reduced graphene oxide. The pre-treatment followed by solar photocatalysis for 120 min under natural sunlight reduced the viable counts of Klebsiella pneumoniae from $2.00 \times 10^{9}$ colony forming units $(\mathrm{CFU}) / \mathrm{mL}$ to below the detection limit (BDL) $(<1 \mathrm{CFU} / 100 \mu \mathrm{L})$. Correspondingly, ethidium monoazide bromide quantitative PCR analysis indicated a high total log reduction in K. pneumoniae gene copies (GC)/mL (5.85 logs after solar photocatalysis for $240 \mathrm{~min}$ ). In contrast, solar disinfection and solar photocatalysis without the biological pre-treatment were more effective for Enterococcus faecium disinfection as the viable counts of E. faecium were reduced by 8.00 logs (from $1.00 \times 10^{8} \mathrm{CFU} / \mathrm{mL}$ to $\mathrm{BDL}$ ) and the gene copies were reduced by $\sim 3.39$ logs (from $2.09 \times 10^{6} \mathrm{GC} / \mathrm{mL}$ to $\sim 9.00 \times 10^{2} \mathrm{GC} / \mathrm{mL}$ ) after $240 \mathrm{~min}$ of treatment. Predatory bacteria can be applied as a pre-treatment to solar disinfection and solar photocatalytic treatment to enhance the removal efficiency of Gram-negative bacteria, which is crucial for the development of a targeted water treatment approach.

Keywords: Harvested rainwater; Bdellovibrio bacteriovorus; Biological pre-treatment; Solar disinfection; Photocatalysis 


\section{Introduction}

Domestic rainwater harvesting is employed as a supplementary water source, particularly in water scarce regions. However, the quality of harvested rainwater does not always comply with drinking water standards, and some bacteria of public health concern such as Pseudomonas, Klebsiella, Campylobacter and Staphylococcus spp., have been detected in rainwater samples (De Kwaadsteniet et al., 2013). While various treatment methods have been investigated and applied to disinfect rainwater (Dobrowsky et al., 2015; Reyneke et al., 2016), the World Health Organisation (WHO) recognises solar disinfection (SODIS) as a cost-effective, household-based technology, which can be employed to decrease the number of viable pathogenic organisms in contaminated water sources and reduce the incidence of diarrheal disease (Byrne et al., 2011). The protocol involves exposing water in UV-visible transparent containers to direct sunlight for a minimum of $6 \mathrm{~h}$ (48 $\mathrm{h}$ in cloudy conditions). Nalwanga et al. (2018) investigated the use of SODIS with $2 \mathrm{~L}$ polyethylene-terephthalate (PET) bottles for the treatment of harvested rainwater in Uganda. While the viable counts of Escherichia coli and faecal enterococci exceeded drinking water standards in the majority of the untreated samples analysed, culture-based analysis indicated that after SODIS, the concentrations of these bacteria were significantly reduced (detailed information on counts not presented) (Nalwanga et al., 2018). The major limitations associated with the use of a simple SODIS system are, however, the small volume of treated water generated ( 1 to $5 \mathrm{~L}$ ) and the treatment time required for sufficient disinfection of the water. It is also recommended that the treated water should be used within $24 \mathrm{~h}$ as regrowth of bacteria may occur (Makwana et al., 2015).

Different approaches have subsequently been investigated to improve the efficiency of solar disinfection. Ubomba-Jaswa et al. (2010) used a $25 \mathrm{~L}$ methacrylate batch reactor fitted with a compound parabolic collector (CPC; concentrates diffuse solar irradiation onto a reactor vessel in order to increase the dose of solar irradiation) to disinfect well water. Complete inactivation of $E$. coli was achieved within $5 \mathrm{~h}$ on sunny days and a 3-log reduction was achieved within this time period during overcast conditions (cloudy days). However, some organisms are more resistant to solar disinfection than others. For example, Strauss et al. (2018) reported that while a solar-CPC treatment system effectively reduced the $E$. coli and total coliform counts to below the detection limit (BDL) at 
temperatures exceeding $39^{\circ} \mathrm{C}$ and UV-A radiation exceeding $20 \mathrm{~W} / \mathrm{m}^{2}$, ethidium monoazide quantitative polymerase chain reaction (EMA-qPCR) analysis indicated that viable Legionella and Pseudomonas were detected in all the SODIS-CPC treated samples throughout the sampling period. Clements et al. (2019) used EMA-qPCR to screen solar pasteurized (SOPAS) harvested rainwater for potentially viable bacteria and found that Klebsiella spp., amongst others, survived at temperatures $>90^{\circ} \mathrm{C}$. It is hypothesised that the survival of bacteria in solar disinfection systems could be due to the possession of heat shock proteins, DNA repair mechanisms (such as recA) and their ability to form associations with protozoa (Strauss et al., 2018). Additional treatment techniques are thus required to overcome this bacterial resistance to disinfection strategies and effectively eliminate these pathogens and opportunistic pathogens from water sources.

Advanced oxidative processes (AOP), such as heterogeneous photocatalysis with semiconductor materials (Byrne et al., 2011), have also been explored and Helali et al. (2014) investigated the solar inactivation of $E$. coli with different photocatalysts [i.e., $\mathrm{TiO}_{2} \mathrm{P} 25, \mathrm{TiO}_{2} \mathrm{PC500}, \mathrm{TiO}_{2}$ Ruana and Russelite $\left(\mathrm{Bi}_{2} \mathrm{WO}_{6}\right)$ ]. With only solar irradiation, 3 to $5 \mathrm{~h}$ were required for complete inactivation of E. coli. In contrast, the treatment time required for the inactivation of $E$. coli was significantly reduced to between 5 to $30 \mathrm{~min}$ for $\mathrm{TiO}_{2} \mathrm{P} 25$, which was the most effective photocatalytic material. We have also previously reported enhanced solar disinfection utilising $\mathrm{TiO}_{2}$-reduced graphene oxide composites ( $\mathrm{TiO}_{2}$-rGO) (Fernández-lbáñez et al., 2015; Cruz-Ortiz et al., 2017). Adán et al. (2018) then showed that $\mathrm{TiO}_{2}$ immobilised on borosilicate glass raschig rings effectively reduced E. coli concentrations, in co-culture with Acanthamoeba trophozoites, by 3 logs in distilled water after $60 \mathrm{~min}$, while a 2 -log reduction was recorded after $180 \mathrm{~min}$ for synthetic wastewater. It was thus concluded that immobilised photocatalysts might be practical for water treatment as the posttreatment removal of the photocatalytic material is not required.

An interesting approach to the inactivation of resistant strains is the use of predatory bacteria such as Bdellovibrio-and-like-organisms (known as BALOs). These have been identified as potential "live antibiotics" as they are able to prey on and reduce the concentration of predominantly Gram-negative bacteria in co-culture experiments (Socket, 2009). This group of predatory bacteria include species such as Bdellovibrio bacteriovorus and Micavibrio aeruginosavorus. Kadouri et al. (2013) 
investigated whether $B$. bacteriovorus and $M$. aeruginosavorus could prey on clinically significant multidrug-resistant Gram-negative bacteria and found that B. bacteriovorus HD100 was able to prey on all the host organisms (100\%), while B. bacteriovorus $109 \mathrm{~J}$ was able to prey on $93 \%$ and M. aeruginosavorus $\mathrm{ARL}-13$ was only able to prey on $35 \%$ of the host bacteria. Limited research has however been conducted on the application of these predatory bacteria as biocontrol agents for potable water treatment, with most studies focussing on their application as probiotics in aquaculture (Chu \& Zhu, 2010; Willis et al., 2016) or as bioremediation agents in wastewater treatment plants (Yu et al., 2017; Ökzan et al., 2018).

Based on the survival of pathogenic microorganisms in treated rainwater, a need exists to investigate a combination of technologies that incorporate biocontrol, physical and chemical treatment. This study thus aimed to apply B. bacteriovorus in combination with solar-CPC reactors and solar-CPC treatment with photocatalysis to disinfect rainwater. Klebsiella pneumoniae $\mathbf{S 1} 43$ (isolated from solar pasteurized rainwater at a treatment temperature above $70^{\circ} \mathrm{C}$ ) (Clements et al., 2019) and Enterococcus faecium 8D (isolated from untreated harvested rainwater) (Dobrowsky et al., 2014) were included as test organisms.

\section{Materials and Methods}

\subsection{Coating of Raschig Rings}

The design and construction of the CPC is outlined in the Supplementary Information. The $\mathrm{TiO}_{2}-\mathrm{rGO}$ composite was synthesised using graphene oxide (GO; Nanoinnova, Spain) and $\mathrm{TiO}_{2}$ P25 (Aeroxide

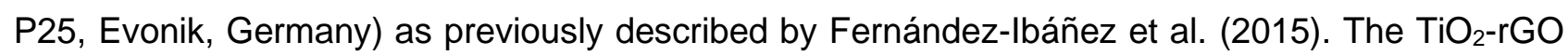
was immobilised on borosilicate glass raschig rings [ $5 \mathrm{~mm}$ (length) $\times 5 \mathrm{~mm}$ (outer diameter) $\times 1 \mathrm{~mm}$ (glass thickness); Sigma-Aldrich, Germany] for application in the designed small-scale solar-CPC systems. The raschig rings were cleaned as described by Cunha et al. (2018). The $\mathrm{TiO}_{2}-\mathrm{rGO}$ (1.5 g) was added to $100 \mathrm{~mL}$ absolute methanol to obtain a final concentration of $1.5 \% \mathrm{w} / \mathrm{v}$. The suspension was sonicated for $15 \mathrm{~min}$ and the raschig rings were submerged in the suspension. To evaporate the methanol, the rings in the suspension were added to a rotary evaporator (Heidolph Instruments, Schwabach $\mathrm{GmbH}$, Germany) with the water bath temperature set to $65^{\circ} \mathrm{C}$ and the rotary speed set 
125 126 127 128 129 130 131 132 133 134

to $120 \mathrm{rpm}$. Once the methanol was evaporated, the coated raschig rings were dried at $80^{\circ} \mathrm{C}$ for $90 \mathrm{~min}$ and annealed at $400^{\circ} \mathrm{C}$ for $2 \mathrm{~h}$ (with a heating rate of $2^{\circ} \mathrm{C}$ per min) in air (Cunha et al., 2018). The rings were weighed before and after the coating, and it was determined that the loading of $\mathrm{TiO}_{2}-\mathrm{rGO}$ was ca. $0.89 \mathrm{mg} / \mathrm{cm}^{2}$.

\subsection{Solar Treatment Experiments}

\subsubsection{Prey Bacterial Strains}

Klebsiella pneumoniae S1 43 and E. faecium 8D were obtained from the Water Resource Laboratory Culture Collection at Stellenbosch University (Department of Microbiology). These bacteria were inoculated into $500 \mathrm{~mL}$ Luria Bertani (LB) broth (Biolab, Merck, South Africa) and were incubated at $37^{\circ} \mathrm{C}$ for 24 to $48 \mathrm{~h}$ with shaking at $200 \mathrm{rpm}$. The bacterial cells were harvested by centrifugation at $11305 \times \mathrm{g}$ for $15 \mathrm{~min}$. The bacterial biomass was washed and re-suspended in phosphate buffered saline (PBS) and the optical density (OD) of the re-suspended pellets was measured using the T60 UV-Visible Spectrophotometer (PG Instruments Limited, Thermo Fisher Scientific, South Africa) at $600 \mathrm{~nm}\left(\mathrm{OD}_{600}\right)$. The concentration of the bacterial cells was adjusted with PBS to obtain a final $\mathrm{OD}_{600}$ of 1.00 (which corresponded to approximately $10^{9}$ cells $/ \mathrm{mL}$ ) (Feng et al., 2016).

\subsubsection{Preparation of the Predatory Bacteria Stock Lysate}

Bdellovibrio bacteriovorus PF13 was isolated from wastewater collected from the influent point of the Stellenbosch Wastewater Treatment Plant (GPS co-ordinates: $33^{\circ} 59^{\prime} 21.13^{\prime \prime} S 18^{\circ} 47^{\prime} 47.75^{\prime \prime E}$ ) as described by Waso et al. (2019). The predatory bacterium was stored as plaques on double-layer agar plates, with Pseudomonas fluorescens ATCC 13525 used as prey cells at $4^{\circ} \mathrm{C}$ until further experimentation commenced (Dashiff et al., 2011). To apply B. bacteriovorus PF13 as a pretreatment to SODIS, a predator stock lysate (used as the predator inoculum in the pre-treatment experiments) was prepared as described by Dashiff et al. (2011) in the presence of $P$. fluorescens ATCC 13525 as prey cells (Supplementary Information). 


\subsubsection{Experimental Set Up}

Synthetic rainwater was used to ensure that the composition of the medium remained constant throughout the study and was prepared by the method reported by Jones and Edwards (1993). For each test organism (K. pneumoniae S1 43 and E. faecium 8D), two experimental groups were analysed as follows: for one experimental group (two systems) the test organisms were pre-treated with B. bacteriovorus; while for the second experimental group (two systems) no pre-treatment occurred (Fig. 1). Additionally, for each experimental group, one solar-CPC system contained $\mathrm{TiO}_{2-}^{-}$ rGO coated raschig rings, while the second system contained uncoated raschig rings (solar disinfection only) (Fig. 1). For the pre-treated samples, $800 \mathrm{~mL}$ of synthetic rainwater was seeded with $100 \mathrm{~mL}$ of $K$. pneumoniae or E. faecium $\left(\mathrm{OD}_{600}=1.00\right)$ (section 2.2.1). Subsequently, each sample was inoculated with $100 \mathrm{~mL}$ of the $B$. bacteriovorus stock lysate $\left(\mathrm{OD}_{600}<0.2\right)$. The co-culture was incubated for $72 \mathrm{~h}$ at $30^{\circ} \mathrm{C}$ with shaking at $200 \mathrm{rpm}$ to allow for the predation of $B$. bacteriovorus on the respective prey cells. For the samples which were not subjected to $B$. bacteriovorus pretreatment, $900 \mathrm{~mL}$ of synthetic rainwater was seeded with $100 \mathrm{~mL}$ of K. pneumoniae or E. faecium cells $\left(\mathrm{OD}_{600}=1.00\right)$ (section 2.2.1) (Fig. 1) on the day of solar treatment.

The four solar-CPC reactors were filled with approximately $390 \mathrm{~mL}$ of the pre-treated or untreated seeded synthetic rainwater samples and were exposed to natural sunlight for $4 \mathrm{~h}$ (Fig. 1). The remaining volume of each sample was kept in the dark and served as dark controls (Fig. 1). Samples $(10 \mathrm{~mL})$ were collected from each solar-CPC system at $0,30,60,90,120,150,180,210$, and $240 \mathrm{~min}$. For each of the collected samples, the $\mathrm{pH}$, temperature, total dissolved solids (TDS), and electrical conductivity (EC) were measured with a hand-held Milwaukee Instruments MI806 meter (Spraytech, South Africa), and the dissolved oxygen (DO) was measured using a Milwaukee Instruments M600 meter (Spraytech). The solar irradiance data [maximum UV-A and UV-B radiation and the maximum direct normal irradiance (DNI)] were obtained from the Stellenbosch Weather Services [Stellenbosch University, Faculty of Engineering (http:// weather.sun.ac.za/)], and the ambient temperature data were obtained from the South African Weather Services (Supplementary Information Tables A.1 and A.2). The results for the conductivity, temperature, pH, TDS, and DO collected for the different solar treatment time points $(0$ to $240 \mathrm{~min}$ ) for each test organism and 
experimental design, are summarised in the Supplementary Information Tables A.1 and A.2. Throughout the text the term "solar disinfection" will refer to solar treatment using only the designed solar-CPC system (with uncoated raschig rings), while "solar photocatalytic disinfection" or "solar photocatalysis" will refer to the solar treatment using the designed solar-CPC system in combination with the immobilised $\mathrm{TiO}_{2}-\mathrm{rGO}$. Furthermore, "solar treatment" will be used to refer simultaneously to both disinfection strategies.

\subsubsection{Culture-based Analysis}

To enumerate the K. pneumoniae and E. faecium cells during the solar treatments [in colony forming units per $\mathrm{mL}(\mathrm{CFU} / \mathrm{mL})]$, samples $(10 \mathrm{~mL})$ were collected as described in section 2.2.3. In addition, for the samples subjected to $B$. bacteriovorus pre-treatment, $10 \mathrm{~mL}$ samples were collected before $(0 \mathrm{~h})$ and after pre-treatment $(72 \mathrm{~h})$. A further $10 \mathrm{~mL}$ sample was collected from each of the dark control samples after 240 min (to confirm that the changes in viable organisms occurred as a result of solar or solar photocatalytic disinfection). A 10-fold serial dilution was prepared (ranging from undiluted to $\left.10^{-6}\right)$ for each sample $(n=40)$, and $100 \mu \mathrm{L}$ of each dilution was spread plated onto LB agar in triplicate. The plates were incubated at $30^{\circ} \mathrm{C}$ for 12 to $18 \mathrm{~h}$ (overnight).

In order to verify that the solar treatment effectively removed the predatory bacteria from the pretreated samples, double-layer agar overlays (as described by Yu et al., 2017) were also prepared using the serial dilutions from the $B$. bacteriovorus pre-treated samples. The plates were incubated at $30^{\circ} \mathrm{C}$ for up to 7 days and the predatory bacteria were enumerated in plaque forming units per $\mathrm{mL}$ (PFU/mL).

\subsubsection{Molecular Analysis}

For the molecular analysis of the solar-CPC samples collected at each time point ( 0 to $240 \mathrm{~min})$ as well as the samples collected before $(0 \mathrm{~h})$ and after $(72 \mathrm{~h})$ B. bacteriovorus pre-treatment, $500 \mu \mathrm{L}$ of each sample was EMA treated as described by Reyneke et al. (2016). The EMA-treated aliquots were subjected to DNA extractions using the Quick-DNA ${ }^{\mathrm{TM}}$ Fecal/Soil Microbe Miniprep kit (Zymo Research, Inqaba Biotech, South Africa) as per the manufacturer's instructions. 
Quantitative real-time PCR was subsequently performed to quantify the gene copies (GC) of B. bacteriovorus, K. pneumoniae and E. faecium during the various solar treatments. All qPCR assays were performed using the LightCycler® 96 Instrument (Roche Diagnostics, Mannheim, Germany) and the FastStart Essential DNA Green Master (Roche Diagnostics). All the qPCR primers and cycling parameters are outlined in Table 1, while the qPCR mixture as described by Waso et al. (2018) was utilised. Additionally, the standard curves utilised for GC quantification in the qPCR assays were generated as described by Waso et al. (2019), using conventional PCR and the cycling parameters defined in Table 1.

All the qPCR results were analysed using the Roche LightCycler® 96 Software Version 1.1 and Microsoft Excel 2016. In addition, the lower limit of detection (LLOD) for each qPCR assay was determined as the lowest concentration $(\mathrm{GC} / \mu \mathrm{L})$ consistently detected in the standard curve samples. Furthermore, the lower limit of quantification (LLOQ) for each qPCR sample was determined as the lowest number of $\mathrm{GC} / \mu \mathrm{L}$ that could reliably be quantified in the standard curve samples. All GC numbers were converted to $\mathrm{GC} / \mathrm{mL}$ using the following modified equation (which excludes compensation for sample filtration) (Eq. 1) as described by Rajal et al. (2007):

$\left(\frac{m L \text { Original Sample }}{m L \text { DNA eluted }}\right) \times(m L$ used per qPCR assay $)=m L$ original sample per qPCR assay

\subsection{Data Analysis}

All graphs were generated using GraphPad Prism 7.04 (2018). Two-way Analysis of Variance (ANOVA) for Multiple Comparisons with Dunnett's tests (alpha value of 0.05) was utilised to determine whether the concentration of the prey bacteria (K. pneumoniae and E. faecium) and B. bacteriovorus changed significantly during the various solar treatments. Significance was observed at $p<0.05$.

\section{Results}

\subsection{Impacts of Different Disinfection Strategies on the Survival of Klebsiella pneumoniae}

For the B. bacteriovorus pre-treated samples, the CFU of $K$. pneumoniae were reduced by 1.92 logs during the 72-h pre-treatment, from $2.00 \times 10^{9}$ (before predation) to $2.40 \times 10^{7} \mathrm{CFU} / \mathrm{mL}$. The PFU 
of $B$. bacteriovorus correspondingly increased by 0.202 logs from $6.53 \times 10^{5} \mathrm{PFU} / \mathrm{mL}$ (before predation) to $1.04 \times 10^{6} \mathrm{PFU} / \mathrm{mL}$. Additionally, EMA-qPCR analysis (characteristics summarised in Table A.3) confirmed that the concentration of $K$. pneumoniae was reduced after predation as the GC of K. pneumoniae decreased by 3.51 logs from $2.95 \times 10^{8}$ (before predation) to $9.20 \times 10^{4} \mathrm{GC} / \mathrm{mL}$, while the concentration of $B$. bacteriovorus increased by 0.430 logs from $7.96 \times 10^{3}$ (before predation) to $2.14 \times 10^{4} \mathrm{GC} / \mathrm{mL}$. Overall, for the dark controls, the plate counts indicated that the concentration of $K$. pneumoniae remained relatively constant with an average of $1.97 \times 10^{7} \mathrm{CFU} / \mathrm{mL}$ and $7.50 \times 10^{8} \mathrm{CFU} / \mathrm{mL}$ recorded (after $240 \mathrm{~min}$ ) for the $72-\mathrm{h}$ B. bacteriovorus pre-treated sample and non-pre-treated sample, respectively.

For the K. pneumoniae pre-treated sample subsequently exposed to solar photocatalytic treatment, culture-based enumeration indicated that within 120 min the $K$. pneumoniae cell counts were reduced by 7.38 logs from $2.40 \times 10^{7} \mathrm{CFU} / \mathrm{mL}$ (at $\left.0 \mathrm{~min}\right)$ to $\mathrm{BDL}(<1 \mathrm{CFU} / 100 \mu \mathrm{L})(p<0.0001)$ (Fig. $2 \mathrm{~A}$; Table 2). Thus, considering the reduction in $\mathrm{CFU} / \mathrm{mL}$ recorded after the $B$. bacteriovorus pretreatment as well as after the solar photocatalytic treatment, the CFU counts of $K$. pneumoniae were reduced by a total of 9.30 logs $(p<0.0001)$ from the initial concentration of $2.00 \times 10^{9} \mathrm{CFU} / \mathrm{mL}$ (Table 2). Correspondingly, EMA-qPCR analysis indicated that in total a 5.85 log reduction in the K. pneumoniae GC was obtained [from $2.95 \times 10^{8} \mathrm{GC} / \mathrm{mL}$ (before predation) to $4.19 \times 10^{2} \mathrm{GC} / \mathrm{mL}$ (after 240 min of solar exposure)] ( $p<0.0001)$ (Fig. 2B; Table 2). The culture-based enumeration of the $B$. bacteriovorus cells analysed indicated that in the samples exposed to solar photocatalytic treatment, the PFU of $B$. bacteriovorus was reduced by 6.02 logs from $1.04 \times 10^{6} \mathrm{PFU} / \mathrm{mL}$ (at $0 \mathrm{~min}$ ) to $\operatorname{BDL}(p<0.0001)$ within 120 min (Fig. A.8A). Similarly, the EMA-qPCR analysis indicated that the concentration of $B$. bacteriovorus was reduced by 2.59 logs $(p<0.0001)$ after solar exposure from an initial concentration of $2.14 \times 10^{4} \mathrm{GC} / \mathrm{mL}$ to $5.49 \times 10^{1} \mathrm{GC} / \mathrm{mL}$ after $240 \mathrm{~min}$ (Fig. A.8B).

For the sample pre-treated with B. bacteriovorus and subsequently exposed to solar disinfection, the cell counts of $K$. pneumoniae were reduced by 7.38 logs from $2.40 \times 10^{7} \mathrm{CFU} / \mathrm{mL}$ (at $0 \mathrm{~min}$ ) to BDL $(p<0.0001)$, after $240 \mathrm{~min}$ of solar exposure (Fig. 2A; Table 2). Thus, the cell counts of K. pneumoniae were also reduced by a total of 9.30 logs $(p<0.0001)$ from the initial concentration of $2.00 \times 10^{9} \mathrm{CFU} / \mathrm{mL}$ (Table 2). In addition, the EMA-qPCR analysis indicated that overall the 
K. pneumoniae concentration was reduced by 5.41 logs from $2.95 \times 10^{8} \mathrm{GC} / \mathrm{mL}$ (before predation) to $1.14 \times 10^{3} \mathrm{GC} / \mathrm{mL}$ (after $240 \mathrm{~min}$ of solar exposure) $(p<0.0001)$ (Fig. 2B; Table 2). The B. bacteriovorus was reduced by 6.02 logs from $1.04 \times 10^{6} \mathrm{PFU} / \mathrm{mL}$ (at $\left.0 \mathrm{~min}\right)$ to $\mathrm{BDL}(p<0.0001)$ within $150 \mathrm{~min}$ in the samples exposed to solar disinfection (Fig. A.8A). Accordingly, the EMA-qPCR analysis indicated that the concentration of $B$. bacteriovorus was reduced by 2.28 logs $(p<0.0001)$ after solar exposure, from an initial concentration of $2.14 \times 10^{4} \mathrm{GC} / \mathrm{mL}$ to $1.12 \times 10^{2} \mathrm{GC} / \mathrm{mL}$ (Fig. A.8B).

In comparison, the cell counts of $K$. pneumoniae in the non-pre-treated sample exposed to solar photocatalytic treatment were reduced by a total of 6.34 logs after $240 \mathrm{~min}$ (from $7.33 \times 10^{8} \mathrm{CFU} / \mathrm{mL}$ to $\left.3.33 \times 10^{2} \mathrm{CFU} / \mathrm{mL}\right)(p<0.0001)($ Fig. $2 \mathrm{~A}$; Table 2), while the molecular analysis indicated that the $\mathrm{GC}$ of $K$. pneumoniae in this sample were reduced by a total of 2.67 logs [from $6.41 \times 10^{7} \mathrm{GC} / \mathrm{mL}$ (initial concentration $0 \mathrm{~min}$ ) to $1.39 \times 10^{5} \mathrm{GC} / \mathrm{mL}$ (after $240 \mathrm{~min}$ of solar exposure)] $(p<0.0001)$ (Fig. 2B; Table 2). Furthermore, for the non-pre-treated sample exposed to only solar disinfection, the cell counts of $K$. pneumoniae were reduced by 8.87 logs from $7.33 \times 10^{8} \mathrm{CFU} / \mathrm{mL}$ (at $0 \mathrm{~min}$ ) to BDL within $210 \min (p<0.0001)$ (Fig. 2A; Table 2). The EMA-qPCR analysis confirmed a reduction in the concentration of the $K$. pneumoniae cells as the GC were reduced by 3.46 logs [from $6.41 \times 10^{7} \mathrm{GC} / \mathrm{mL}$ (initial concentration $0 \mathrm{~min}$ ) to $2.24 \times 10^{4} \mathrm{GC} / \mathrm{mL}$ (after $240 \mathrm{~min}$ of solar exposure)] $(p<0.0001)$ in this sample (Table 2$).$

\subsection{Impacts of Different Disinfection Strategies on the Survival of Enterococcus faecium}

For the $B$. bacteriovorus pre-treated samples, the culture-based enumeration indicated that the E. faecium cell counts were reduced by 0.598 logs from $3.57 \times 10^{9}$ (before predation) to $9.00 \times 10^{8} \mathrm{CFU} / \mathrm{mL}$ (after $72 \mathrm{~h}$ of predation). The EMA-qPCR analysis then confirmed that the concentration of $E$. faecium was reduced after $72 \mathrm{~h}$ of predation from $8.24 \times 10^{5} \mathrm{GC} / \mathrm{mL}$ (before predation) to $1.60 \times 10^{5} \mathrm{GC} / \mathrm{mL}$ with a log reduction of 0.712 recorded. While, $B$. bacteriovorus did not produce any plaques on the double-layer agar overlays when E. faecium was utilised as prey, the EMA-qPCR analysis indicated that the concentration of B. bacteriovorus decreased by 0.167 logs from $1.08 \times 10^{4}$ (before predation) to $7.34 \times 10^{3} \mathrm{GC} / \mathrm{mL}$ (after $72 \mathrm{~h}$ of predation). Overall, for 
the dark controls, the plate counts indicated that the concentration of E. faecium remained relatively constant with an average of $4.17 \times 10^{8} \mathrm{CFU} / \mathrm{mL}$ and $1.63 \times 10^{8} \mathrm{CFU} / \mathrm{mL}$ recorded (after $240 \mathrm{~min}$ ) for the 72-h B. bacteriovorus pre-treated sample and non-pre-treated sample, respectively.

Subsequently, the cell counts of E. faecium recorded for the pre-treated sample exposed to solar photocatalysis were reduced by 3.81 logs from $9.00 \times 10^{8} \mathrm{CFU} / \mathrm{mL}$ (at $0 \mathrm{~min}$ ) to $1.40 \times 10^{5} \mathrm{CFU} / \mathrm{mL}$ (at $240 \mathrm{~min})(p<0.0001)$ (Fig. 3A). Thus, the CFU/mL of E. faecium was reduced by a total of 4.41 logs from an initial concentration of $3.57 \times 10^{9} \mathrm{CFU} / \mathrm{mL}$ (Table 2). The EMA-qPCR analysis then indicated that the E. faecium concentration was reduced by 1.57 logs from $1.60 \times 10^{5} \mathrm{GC} / \mathrm{mL}$ (at $0 \mathrm{~min}$ ) to $4.35 \times 10^{3} \mathrm{GC} / \mathrm{mL}$ (at $240 \mathrm{~min}$ ) (Fig. 3B), with an overall reduction of 2.28 logs recorded from an initial concentration of $8.24 \times 10^{5} \mathrm{GC} / \mathrm{mL}$ (Table 2). As mentioned previously, B. bacteriovorus did not produce any plaques on the double-layer agar overlays when $E$. faecium was utilised as prey and the EMA-qPCR analysis indicated that the concentration of $B$. bacteriovorus was reduced from an initial concentration of $7.34 \times 10^{3} \mathrm{GC} / \mathrm{mL}$ (at $0 \mathrm{~min}$ ) to $8.13 \times 10^{2} \mathrm{GC} / \mathrm{mL}(0.956$ log reduction; $p<0.0001$ ) after 240 min of solar photocatalysis (Fig. A.9).

The cell counts of $E$. faecium recorded for the pre-treated sample exposed to solar disinfection, were reduced by 6.73 logs from $9.00 \times 10^{8} \mathrm{CFU} / \mathrm{mL}$ (at $0 \mathrm{~min}$ ) to $1.67 \times 10^{2} \mathrm{CFU} / \mathrm{mL}$ (at $240 \mathrm{~min}$ ) $(p<0.0001)$ (Fig. 3A; Table 2). Therefore, an overall log reduction of 7.33 in $E$. faecium $\mathrm{CFU} / \mathrm{mL}$ was recorded after the $B$. bacteriovorus pre-treatment and solar disinfection (Table 2). The EMAqPCR analysis indicated that the concentration of E. faecium was reduced by 2.09 logs from $1.60 \times 10^{5} \mathrm{GC} / \mathrm{mL}$ (at $0 \mathrm{~min}$ ) to $1.29 \times 10^{3} \mathrm{GC} / \mathrm{mL}$ (at $\left.240 \mathrm{~min}\right)(p<0.0001)$ (Fig. 3B). Overall, the concentration of E. faecium was thus reduced by a total of 2.81 logs in the pre-treated sample exposed to solar disinfection, from an initial concentration of $8.24 \times 10^{5} \mathrm{GC} / \mathrm{mL}$ (Table 2). For the predatory bacteria, the EMA-qPCR analysis indicated that the concentration of $B$. bacteriovorus was reduced from an initial concentration of $7.34 \times 10^{3} \mathrm{GC} / \mathrm{mL}$ (at $0 \mathrm{~min}$ ) to $8.95 \times 10^{2} \mathrm{GC} / \mathrm{mL}(0.914 \log$ reduction; $p<0.0001$ ) after 240 min of solar exposure (Fig. A.9).

For the samples which were not pre-treated with B. bacteriovorus but exposed to solar disinfection and solar photocatalytic treatment, the culture-based enumeration of E. faecium indicated that for 
both treatment methods, the cell counts were reduced by 8.00 logs from an initial concentration of $1.00 \times 10^{8} \mathrm{CFU} / \mathrm{mL}$ to $\mathrm{BDL}(<1 \mathrm{CFU} / 100 \mu \mathrm{L})$ within $210 \mathrm{~min}$ of solar exposure $(p<0.0001)$ (Fig. 3A; Table 2). The EMA-qPCR analysis then indicated that during solar disinfection the concentration of E. faecium was reduced by 3.39 logs from $2.09 \times 10^{6} \mathrm{GC} / \mathrm{mL}$ (at $0 \mathrm{~min}$ ) to $8.53 \times 10^{2} \mathrm{GC} / \mathrm{mL}$ (at 240 $\min )(p<0.0001)$ (Fig. 3B; Table 2). Similarly, for the sample exposed to solar photocatalytic treatment, the concentration of E. faecium was reduced by 3.38 logs from $2.09 \times 10^{6} \mathrm{GC} / \mathrm{mL}$ (at $0 \mathrm{~min}$ ) to $8.74 \times 10^{2} \mathrm{GC} / \mathrm{mL}$ (at $\left.240 \mathrm{~min}\right)(p<0.0001)$ (Fig. 3B; Table 2).

\section{Discussion}

While disinfection methods are effective in significantly reducing the concentration of microbial contaminants in water sources, various pathogens and opportunistic pathogens employ survival strategies and persist after treatment (Strauss et al., 2018; Clements et al., 2019). It was thus proposed in the current study that a combination of physical, chemical and biological treatments, could prove effective in eliminating disinfection resistant species. Bdellovibrio bacteriovorus is known to attach to the cell wall of Gram-negative prey, such as K. pneumoniae, through an unknown mechanism or receptor, whereafter the predator rotates to create a pore in the prey cell wall and enters the prey cell's periplasmic space forming a structure called the bdelloplast (Sockett, 2009). Once the predator has invaded the prey cell, it secretes various hydrolytic enzymes to break down the prey cell's constituents and produce progeny (Sockett, 2009). Correspondingly, as K. pneumoniae is sensitive to predation, the pre-treatment with $B$. bacteriovorus aided in effectively reducing the concentration of this organism in the seeded water samples. Furthermore, the addition of the photocatalytic material enhanced the disinfection efficiency as the treatment time required to reduce the K. pneumoniae CFU to BDL was decreased from $240 \mathrm{~min}$ (solar disinfection) to $120 \mathrm{~min}$ (solar photocatalysis). Under solar UV-visible exposure, the $\mathrm{TiO}_{2}-\mathrm{rGO}$ composite photocatalytic material produces reactive oxygen species (ROS), which significantly disrupts the cell membrane structures and damages DNA and RNA, ultimately leading to cell death (Byrne et al., 2011).

We previously investigated the mechanisms behind the antimicrobial activity of $\mathrm{TiO}_{2}$-rGO in water using E. coli as the model organism (Fernández-lbáñez et al., 2015; Cruz-Ortiz et al., 2017). 
Fernández-lbáñez et al. (2015) reported that E. coli was reduced by 6 logs (within 10 min, less than $2 \mathrm{~J} / \mathrm{cm}^{2}$ ) under natural sunlight with a photocatalyst loading of $500 \mathrm{mg} / \mathrm{L}$. Probes were used to investigate the primary ROS produced during the disinfection experiments and we found that under UV-visible light, hydrogen peroxide, hydroxyl radicals and singlet oxygen were mainly responsible for the reduction in $E$. coli concentrations. Under visible light irradiation, only singlet oxygen was produced which resulted in the reduction of the E. coli concentration (Fernández-lbáñez et al., 2015; Cruz-Ortiz et al., 2017). Lin et al. (2014) investigated the cytotoxic effects of UV excited $\mathrm{TiO}_{2}$ on Gram-negative bacteria by also employing E. coli as the test organism. With the use of transmission electron microscopy, the authors found that the $\mathrm{TiO}_{2}$ nanoparticles attached to the outside of the E. coli cells, while some microbial cells were also observed to contain internalised nanoparticles. It was concluded that the nanoparticles attached to the cell surface, induced cell distortion, plasmolysis and extensive cell wall and membrane damage. In addition, the authors hypothesised that the attachment of the nanoparticles to the cells resulted in decreased movement of substances into and out of the bacterial cells, ultimately resulting in homeostatic imbalances and cellular metabolic disturbances, which would eventually result in cell death (Lin et al., 2014).

However, while Lin et al. (2014) evaluated the photocatalyst in suspension, in the current study, the photocatalyst was immobilised onto glass raschig rings and exposed to real solar irradiation. Sordo et al. (2010) compared the use of $\mathrm{TiO}_{2}$ in suspension to $\mathrm{TiO}_{2}$ immobilised onto a glass tube (used as the reactor vessel) and raschig rings for the disinfection of $E$. coli in a recirculating solar treatment system. The authors found that the disinfection of $E$. coli in the reactor with the $\mathrm{TiO}_{2}$ coated raschig rings, was comparable to the disinfection obtained in the reactor with $\mathrm{TiO}_{2}$ in suspension, while disinfection efficiency was not enhanced in the glass tube reactor vessel coated with the photocatalyst. It was hypothesised that the high disinfection efficiency obtained with the raschig ring immobilised photocatalyst was due to the greater contact area generated, which increased exposure of the E. coli cells to hydroxyl radicals produced during the photocatalytic process. However, the authors also noted that the flow rate generated in the recirculating system containing the raschig rings, greatly enhanced the disinfection efficiency of the reactor as strong mechanical stress was exerted on the bacterial cells (Sordo et al., 2010). The use of raschig rings as support materials for 
the immobilisation of photocatalysts is thus advantageous as post-treatment removal of the material is not required. In addition, immobilising the photocatalyst creates a greater contact area which may increase the exposure of the cells to the photocatalytic material. Furthermore, if a flow rate is applied, mechanical stress is exerted on the cells.

Apart from using photocatalytic material in two of the solar-CPC reactors in the current study, all the water samples (pre-treated with $B$. bacteriovorus and non-pre-treated) were exposed to solar treatment under CPC concentrated solar UV-A radiation. The CPC mirrors were used for the solar treatment reactors as it significantly enhances any kind of solar water treatment by improving the solar UV energy income by a concentration factor of 1 (Keane et al., 2014). Navntoft et al. (2008) demonstrated that the use of a CPC accelerated the reduction of 6-log E. coli K12 under solar disinfection by 90 minutes as compared to a PET plastic bottle. Based on the solar UV-A dose calculated for the K. pneumoniae trials (Supplementary Information), a similar UV-A dose was obtained within $120 \mathrm{~min}$ of solar exposure $\left(25.83 \mathrm{~J} \mathrm{~cm}^{-2}\right)$, to the dose reported in literature $\left(27 \mathrm{~J} / \mathrm{cm}^{2}\right)$ to achieve a 5-log reduction in E. coli $\mathrm{K} 12$ by solar disinfection in a 2 L-PET bottle filled with clear transparent water (Castro-Alférez et al., 2018). Additionally, the dose obtained in the current study was 10 times higher than the $1.8 \mathrm{~J} / \mathrm{cm}^{2}\left(10 \mathrm{~min}\right.$ at $30 \mathrm{~W} / \mathrm{m}^{2}$ of solar UV-A) required to achieve a 6 log reduction of $E$. coli $\mathrm{K} 12$ using the same catalyst $\left(\mathrm{TiO}_{2}-\mathrm{rGO}\right)$ suspended as a slurry at a concentration of 500 mg/L (Fernández-lbáñez et al., 2015). Similar solar dose values were obtained for the E. faecium trial. Thus, sufficient solar irradiation was obtained to reduce the concentration of K. pneumoniae and E. faecium during the current study.

Correspondingly, the most efficient treatment strategy for the reduction of E. faecium was the use of solar disinfection or solar photocatalytic disinfection without $B$. bacteriovorus pre-treatment. While it is generally theorised that $B$. bacteriovorus does not prey on Gram-positive bacteria, studies have indicated that this predator can prey on Staphylococcus aureus (lebba et al., 2014; Pantanella et al., 2018). The lytic enzymes produced by $B$. bacteriovorus have also been shown to disrupt biofilms produced by Gram-positive bacteria, while proteases produced by $B$. bacteriovorus can decrease the efficiency of $S$. aureus invasion into human epithelial cells (Monnappa et al., 2014). Furthermore, using culture-based methods and EMA-qPCR, we have recently reported that $B$. bacteriovorus PF13 
can reduce the concentration of $S$. aureus and E. faecium in co-culture experiments (Waso et al., 2019). Thus, while it is warranted to investigate the effect of $B$. bacteriovorus pre-treatment on the disinfection of Gram-positive bacteria, in this study pre-treatment with B. bacteriovorus PF13 did not significantly reduce the concentration of E. faecium.

Based on the results obtained for the $E$. faecium trials, the addition of the photocatalyst also did not significantly enhance the disinfection efficiency. Gutiérrez-Alfaro et al. (2015) compared three systems to disinfect potable water inoculated with wastewater containing E. coli, Enterococcus spp. and Clostridium perfringens: a 2 L PET bottle; a 2 L PET bottle with an internal cylinder coated with $\mathrm{TiO}_{2}$ doped with zinc; and a glass reactor $(9 \mathrm{~L})$ with a $\mathrm{TiO}_{2}$ coated inner cylinder. In all the systems analysed, E. coliwas readily reduced to BDL, while Enterococcus spp. and C. perfringens were more resistant to disinfection. In addition, the immobilised photocatalyst used in the 2 L PET bottles only enhanced the disinfection efficiency of the SODIS bottles by 0.43 logs for E. coli, 0.45 logs for Enterococcus spp. and 0.28 logs for C. perfringens under natural sunlight (Gutiérrez-Alfaro et al., 2015). The authors ultimately concluded that Gram-positive bacteria, which have more complex cell walls, are more resistant to disinfection in comparison to Gram-negative bacteria. However, they found that recirculating the water in the solar photocatalytic systems, increased turbulence and contact between the catalyst and the bacteria, significantly enhancing the disinfection efficiency, especially for Gram-positive bacteria (Gutiérrez-Alfaro et al., 2015). Veneiri et al. (2014) also investigated the disinfection of Enterococcus faecalis using $\mathrm{TiO}_{2} \mathrm{P} 25$ (200 mg/L to $\left.1500 \mathrm{mg} / \mathrm{L}\right)$ and SODIS under simulated sunlight, using culture-based methods and qPCR. The culturing results indicated that at the highest $\mathrm{TiO}_{2}$ concentration $(1500 \mathrm{mg} / \mathrm{L})$, E. faecalis was reduced by 7 logs to BDL after approximately 40 min of treatment. Similarly, while qPCR analysis indicated that a 7-log reduction in the $\mathrm{GC}$ of $E$. faecalis was obtained after 120 min of treatment, the $\mathrm{GC}$ were not reduced to BDL in any of the treated samples. The authors concluded that viable but non-culturable (VBNC) E. faecalis cells were still present in the treated samples and that the SODIS treatment time should be extended in order to eradicate $E$. faecalis (Veneiri et al., 2014).

Similarly, in the current study, for all the treatment combinations analysed, EMA-qPCR results indicated that the GC of K. pneumoniae and E. faecium were not reduced to BDL, signifying that 
VBNC cells may still have persisted. While numerous research groups have detected Klebsiella spp. in untreated harvested rainwater (De Kwaadsteniet et al., 2013), the K. pneumoniae strain (S1 43) employed in the current study was isolated from SOPAS rainwater at a treatment temperature above $70^{\circ} \mathrm{C}$ (Clements et al., 2019). The thermal tolerance of Klebsiella spp. has been associated with the expression of heat shock proteins or can be acquired through plasmids encoding for ClpK ATPase (Bojer et al., 2011). Moreover, K. pneumoniae have prominent capsules which have been hypothesised to protect this organism from bactericidal stressors such as UV irradiation and antibiotic agents (Veneiri et al., 2017; Dorman et al., 2018). In contrast, the E. faecium strain (8D) employed was isolated from untreated harvested rainwater (Dobrowsky et al., 2014). Enterococcus spp. are known to tolerate a wide range of environmental conditions and they have been found to exhibit increased resistance to UV disinfection (McKinney \& Pruden, 2012; Maraccini et al., 2012). Some strains of enterococci have been found to possess intracellular carotenoids which may act as quenchers of intracellularly produced ROS upon exposure to sunlight, ultimately protecting the cell from increasing oxidative stress and providing Enterococcusspp. with a competitive advantage against sunlight-induced inactivation (Maraccini et al., 2012). Gram-negative and Gram-positive bacteria also possess DNA repair mechanisms, which can repair damage induced by UV irradiation, and allow bacterial cells to persist and survive after UV disinfection (McGuigan et al., 2012). Thus, while the molecular analysis results obtained in the current study indicated that significant reductions $(p<0.0001)$ in $\mathrm{GC}$ were recorded (Fig. 2B and 3B), further work may include extending the solar disinfection and solar photocatalytic treatment time.

\section{Conclusions}

Based on the results obtained, $B$. bacteriovorus may be applied to decrease the concentration of Gram-negative bacteria, such as K. pneumoniae, prior to solar disinfection. This is crucial as many pathogenic Gram-negative bacteria have been found to persist after the implementation of various disinfection strategies. Solar disinfection or solar photocatalytic treatment successfully reduced the concentration of $E$. faecium and it is likely that forced convection in a solar photocatalytic system may further enhance the effect of the photocatalytic material on the disinfection of Gram-positive bacteria. 
Furthermore, as hydroxyl radicals produced during photocatalysis significantly disrupts the cell membrane of bacteria (Polo-López et al., 2017), the use of EMA-qPCR is recommended to supplement culture-based analysis and should therefore be included in future studies monitoring such water treatment systems. As natural water sources will contain mixed bacterial communities, future research should investigate the effect of predatory bacteria pre-treatment on mixed bacterial communities in natural water sources, to assess the overall effect of $B$. bacteriovorus pre-treatment.

\section{Acknowledgements}

The authors would like to acknowledge the following individuals and institutions for their contribution to this project:

- The financial assistance of the Deutscher Akademischer Austauschdienst (DAAD) / National Research Foundation (NRF) of South Africa and the Royal Society Newton Mobility Grant (Grant number: N1170184). Opinions expressed and conclusions arrived at, are those of the authors and are not necessarily to be attributed to the DAAD/NRF or the Royal Society Newton Mobility Grant.

- Pilar Fernández-lbáñez and John Anthony Byrne acknowledge funding from Global Challenges Research Fund - United Kingdom Research and Innovation (GCRF UKRI) for SAFEWATER (Grant Ref number EP/P032427/1).

- Dr Jeremy Hamilton and Dr Preetam Sharma from the Nanotechnology and Integrated BioEngineering Centre (NIBEC) at Ulster University (Northern Ireland) for their guidance during the synthesis and immobilisation of the $\mathrm{TiO}_{2}-\mathrm{rGO}$ material.

- Casper Brink from the Microbiology Department at Stellenbosch University for creating the drawings of the designed SODIS systems in AutoCAD® 2018.

- Dr Pieter Neethling from the Physics Department at Stellenbosch University for measuring the reflectance of the stainless-steel sheets utilised for the construction of the compound parabolic collectors. 


\section{Declaration of Interest}

477 The authors declare no conflict of interest.

478

479

480

481

482

483

484

485

486

487

488

489

490

491

492

493

494

495

496

497

498

499

500

\section{References}

Adán, C., Magnet, A., Fenot, S., Pablos, C., Del Águila, C., Marugán, J., 2018. Concomitant inactivation of Acanthamoeba spp. and Escherichia coli using suspended and immobilized $\mathrm{TiO}_{2}$. Water Research 144, 512-521.

Bojer, M. S., Krogfelt, K. A., Struve, C., 2011. The newly discovered ClpK protein strongly promotes survival of Klebsiella pneumoniae biofilm subjected to heat shock. Journal of Medical Microbiology 60(10), 1559-1561.

Brisse, S., Verhoef, J., 2001. Phylogenetic diversity of Klebsiella pneumoniae and Klebsiella oxytoca clinical isolates revealed by randomly amplified polymorphic DNA, gyrA and parC gene sequencing and automated ribotyping. International Journal of Systematic and Evolutionary Microbiology 51, 915-924.

Byrne, J.A., Fernández-lbáñez, P.A., Dunlop, P.S., Alrousan, D.M., Hamilton, J.W., Abdel-Mottaleb, M.S., 2011. Photocatalytic enhancement for solar disinfection of water: A review. International Journal of Photoenergy 2011, 1-12.

Castro-Alférez, M., Polo-López, M.I., Marugán, J., Fernández-lbáñez, P., 2018. Validation of a solarthermal water disinfection model for Escherichia coli inactivation in pilot scale solar reactors and real conditions. Chemical Engineering Journal 331, 831-840.

Chu, W.H., Zhu, W., 2010. Isolation of Bdellovibrio as biological therapeutic agents used for the treatment of Aeromonas hydrophila infection in fish. Zoonoses and Public Health 57(4), 258-264.

Clements, T.L., Reyneke, B., Strauss, A., Khan, W., 2019. Persistence of viable bacteria in solar pasteurised harvested rainwater. Water Air Soil Pollution 230(130), 1-13.

Cruz-Ortiz, B.R., Hamilton, J., Pablos, C., Díaz-Jiménez, L., Cortés-Hernández, D.A., Sharma, P.K., Castro-Alférez, M., Fernández-lbáñez, P., Dunlop, P.S.M., Byrne, J.A., 2017. Mechanism of 
photocatalytic disinfection using titania-graphene composites under UV and visible irradiation. Chemical Engineering Journal 316, 179-186.

Cunha, D.L., Kuznetsov, A., Achete, C.A., Da Hora Machado, A.E., Marques, M., 2018. Immobilized $\mathrm{TiO}_{2}$ on glass spheres applied to heterogeneous photocatalysis: Photoactivity, leaching and regeneration process. PeerJ Environmental Science 6, e4464.

Dashiff, A., Junka, R.A., Libera, M., Kadouri, D.E., 2011. Predation of human pathogens by the predatory bacteria Micavibrio aeruginosavorus and Bdellovibrio bacteriovorus. Journal of Applied Microbiology 110(2), 431-444.

De Kwaadsteniet, M., Dobrowsky, P.H., Van Deventer, A., Khan, W., Cloete, T.E., 2013. Domestic rainwater harvesting: Microbial and chemical water quality and point-of-use treatment systems. Water Air Soil Pollution 224(7), 1-19.

Dobrowsky, P.H., De Kwaadsteniet, M., Cloete, T.E., Khan, W., 2014. Distribution of indigenous bacterial pathogens and potential pathogens associated with roof-harvested rainwater. Applied and Environmental Microbiology 80 (7), 2307-2316.

Dobrowsky, P.H., Lombard, M., Cloete, W.J., Saayman, M., Cloete, T.E., Carstens, M., Khan, S., Khan, W., 2015. Efficiency of microfiltration systems for the removal of bacterial and viral contaminants from surface and rainwater. Water Air Soil Pollution 226, 1-14.

Dorman, M.J., Feltwell, T., Goulding, D.A., Parkhill, J., Short, F.L., 2018. The capsule regulatory network of Klebsiella pneumoniae defined by density-TraDISort. Molecular Biology and Physiology 9(6), 1-19.

Feng, S., Tan, C.H., Cohen, Y., Rice, S.A., 2016. Isolation of Bdellovibrio bacteriovorus from a tropical wastewater treatment plant and predation of mixed species biofilms assembled by the native community members. Environmental Microbiology 18(11), 3923-3931.

Fernández-lbáñez, P., Polo-López, M.I., Malato, S., Wadhwa, S., Hamilton, J.W.J., Dunlop, P.S.M., D’Sa, R., Magee, E., O’Shea, K., Dionysiou, D.D., Byrne, J.A., 2015. Solar photocatalytic disinfection of water using titanium dioxide graphene composites. Chemical Engineering Journal 261, 36-44. 
Frahm, E., Obst, U., 2003. Application of the fluorogenic probe technique (TaqMan PCR) to the detection of Enterococcus spp. and Escherichia coli in water samples. Journal of Microbiological Methods 52(1), 123-131.

Gutiérrez-Alfaro, S., Acevedo, A., Rodríguez, J., Carpio, E.A., Manzano, M.A., 2015. Solar photocatalytic water disinfection of Escherichia coli, Enterococcus spp. and Clostridium perfringens using different low-cost devices. Journal of Chemical Technology and Biotechnology 91(7), 20262037.

Helali, S., Polo-López, M.I., Fernández-lbáñez, P., Ohtanu, B., Amano, F., Malato, S., Guillard, C., 2014. Solar photocatalysis: A green technology for E. coli contaminated water disinfection. Effect of concentration and different types of suspended catalyst. Journal of Photochemistry and Photobiology A: Chemistry 276, 31-40.

lebba, V., Totino, V., Santangelo, F., Gagliardi, A., Ciotoli, L., Virga, A., Ambrosi, C., Pompili, M., De Biase, R.V., Selan, L., Artini, M., Pantanella, F., Mura, F., Passariello, C., Nicoletti, M., Nencioni, L., Trancassini, M., Quattrucci, S., Schippa, S., 2014. Bdellovibrio bacteriovorus directly attacks Pseudomonas aeruginosa and Staphylococcus aureus cystic fibrosis isolates. Frontiers in Microbiology 5(280), 1-9.

Jones, D.L., Edwards, A.C., 1993. Evaluation of polysulfone hollow fibres and ceramic suction samplers as devices for the in situ extraction of soil solution. Plant and Soil 150(2), 157-165.

Kadouri, D.E., To, K., Shanks, R.M.Q., Doi, Y., 2013. Predatory bacteria: a potential ally against multi-drug resistant Gram-negative pathogens. PLOS One 8 (5), e63397.

Keane, D.A., McGuigan, K.G., Fernández-Ibáñez, P., Polo-López, M.I., Byrne, J.A., Dunlop, P.S.M, O'Shea, K., Dionysiou, D.D., Pillai, S.C., 2014. Solar photocatalysis for water disinfection: Materials and reactor design. Catalysis Science \& Technology 4, 1211-1226.

Lin, X., Li, J., Ma, S., Liu, G., Yang, K., Tong, M., Lin, D., 2014. Toxicity of $\mathrm{TiO}_{2}$ nanoparticles to Escherichia coli: Effects of particle size, crystal phase and water chemistry. PLOS One 9 (10), e110247. 
Makwana, N.M., Hazael, R., McMillan, P.F., Darr, J.A., 2015. Photocatalytic water disinfection by simple and low-cost monolithic and heterojunction ceramic wafers. Photochemical and Photobiological Sciences 14, 1190-1196.

Maraccini, P.A., Ferguson, D.M., Boehm, A.B., 2012. Diurnal variation in Enterococcus species composition in polluted ocean water and a potential role for the enterococcal carotenoid in protection against photoinactivation. Applied and Environmental Microbiology 78, 305-310.

McGuigan, K.G., Conroy, R.M., Mosler, H., Du Preez, M., Ubomba-Jaswa, E., Fernández-lbáñez, P., 2012. Solar water disinfection (SODIS): A review from bench-top to roof-top. Journal of Hazardous Materials 235-236, 29-46.

McKinney, C.W., Pruden, A., 2012. Ultraviolet disinfection of antibiotic resistant bacteria and their antibiotic resistance genes in water and wastewater. Environmental Science and Technology 46(24), 13393-13400.

Monnappa, A.K., Dwidar, M., Seo, J.K., Hur, J., Mitchel, R.J., 2014. Bdellovibrio bacteriovorus inhibits Staphylococcus aureus biofilm formation and invasion into human epithelial cells. Nature Scientific Reports 4 (3811), 1-8.

Nalwanga, R., Muyanja, C.K., McGuigan, K.G., Quilty, B., 2018. A study of the bacteriological quality of roof-harvested rainwater and an evaluation of SODIS as a suitable treatment technology in rural Sub-Saharan Africa. Journal of Environmental Chemical Engineering 6(3), 3648-3655.

Navntoft, C., Ubomba-Jaswa, E., McGuigan, K.G., Fernández-lbáñez, P., 2008. Effectiveness of solar disinfection using batch reactors with non-imaging aluminium reflectors under real conditions: Natural well water and solar light. Journal of Photochemistry and Photobiology B: 93, 155-161.

Özkan, M., Yilmaz, H., Çelik, M.A., Şengezer, Ç., Erhan, E., 2018. Application of Bdellovibrio bacteriovorus for reducing fouling of membranes used for wastewater treatment. Turkish Journal of Biochemistry 43, 296-305. 
Pantanella, F., lebba, V., Mura, F., Dini, L., Totino, V., Neroni, B., Bonfiglio, G., Maria, T., Passariello, C., Schippa, S., 2018. Behaviour of Bdellovibrio bacteriovorus in the presence of Gram-positive Staphylococcus aureus. The New Microbiologica 41(2),145-152.

Polo-López, M.I., Castro-Alférez, M., Nahim-Granados, S., Malato, S., Fernández-lbáñez, P., 2017. Legionella jordanis inactivation in water by solar driven processes: EMA-qPCR versus culture-based analyses for new mechanistic insights. Catalysis Today 287, 15-21.

Rajal, V., McSwain, B., Thompson, D., Leutenegger, C., Wuertz, S., 2007. Molecular quantitative analysis of human viruses in California stormwater. Water Research 41(19), 4287-4298.

Reyneke, B., Dobrowsky, P.H., Ndlovu, T., Khan, S., Khan, W., 2016. EMA-qPCR to monitor the efficiency of a closed-coupled solar pasteurization system in reducing Legionella contamination of roof-harvested rainwater. Science of the Total Environment 553, 662-670.

Sockett, R.E., 2009. Predatory Lifestyle of Bdellovibrio bacteriovorus. Annual Review of Microbiology $63,523-539$.

Sordo, C., Van Grieken, R., Marugán, J., Fernández-lbáñez, P., 2010. Solar photocatalytic disinfection with immobilised $\mathrm{TiO}_{2}$ at pilot-plant scale. Water Science and Technology 61(2), 507512.

Strauss, A., Reyneke, B., Waso, M., Ndlovu, T., Khan, S., Khan, W. 2018. Compound parabolic collector solar disinfection for the treatment of harvested rainwater. Environmental Science: Water Research \& Technology 4, $976-991$.

Ubomba-Jaswa, E., Fernández-lbáñez, P., Navntoft, C., Polo-López, M.I., McGuigan, K.G., 2010. Investigating the microbial inactivation efficiency of a $25 \mathrm{~L}$ batch solar disinfection (SODIS) reactor enhanced with a compound parabolic collector (CPC) for household use. Journal of Chemical Technology and Biotechnology 85(8), 1028-1037.

Van Essche, M., Sliepen, I., Loozen, G., Van Eldere, J., Quirynen, M., Davidov, Y., Jurkevitch, E., Boon, N., Teughels, W., 2009. Development and performance of quantitative PCR for the enumeration of Bdellovibrionaceae. Environmental Microbiology Reports 1(4), 228-233. 
603 Venieri, D., Fraggedaki, A., Kostadima, M., Chatzisymeon, E., Binas, V., Zachopoulos, A., Kiriakidis, 604 G., Mantzavinos, D., 2014. Solar light and metal-doped $\mathrm{TiO}_{2}$ to eliminate water-transmitted bacterial 605 pathogens: Photocatalyst characterization and disinfection performance. Applied Catalysis B: 606 Environmental 154-155, 93-101.

607 Veneiri, D., Gounaki, I., Bikouvaraki, M., Binas, V., Zachopoulos, A., Kiriakidis, G., Mantzavinos, D., 608 2017. Solar photocatalysis as disinfection technique: Inactivation of Klebsiella pneumoniae in 609 sewage and investigation of changes in antibiotic resistance profile. Journal of Environmental 610 Management 195(2), 140-147.

611 Waso, M., Khan, S., Khan, W., 2018. Microbial source tracking markers associated with domestic 612 rainwater harvesting systems: Correlation to indicator organisms. Environmental Research 161, $613 \quad 446-455$.

614 Waso, M., Khan, S., Khan, W., 2019. Assessment of predatory bacteria and prey interactions using 615 culture-based methods and EMA-qPCR. Microbiological Research 228, 1 - 10.

616 Willis, A.R., Moore, C., Mazon-Moya, M., Krokowski, S., Lambert, C., Till, R., Mostowy, S., Sockett, 617 R.E., 2016. Injections of predatory bacteria work alongside host immune cells to treat Shigella 618 infection in zebrafish larvae. Current Biology 26, 3343-3351.

619 Yu, R., Zhang, S., Chen, Z., Li, C., 2017. Isolation and application of predatory Bdellovibrio-and-like 620 organisms for municipal waste sludge biolysis and dewaterability enhancement. Frontiers of 621 Environmental Science \& Engineering 11(10), 1-11. 